\section{$10666 j=$ \\ A New Notation and Enumeration System for Organic Compounds}

By Dr. G. Malcolm Dyson. Second edition. Pp. ix +138. (London, New York and Toronto : Longmans, Green and Co., Ltd., 1949.) 10s. $6 d$. net.

$\mathrm{W}$ HILE the main general principles of the original notation are retained in this second edition, some changes have been made, and the new edition is offered definitive proposal for an international sxstem for delineating and enumerating organic inuthe In the description of ring systems the Rinciple of adduction is abandoned in favour of a more logical statement of the reticular system. Suggestions made by Dr. A. M. Patterson for reconciling the logic of the new notation with that of the ring index, and with suggestions of Dr. F. L. Taylor for ring citation, are incorporated in the section dealing with fused rings. Another major revision is the rearrangement of symbols within the operations, which is intended to facilitate indexing and the manipulation of punched card data.

Besides these changes, the book has been considerably enlarged, and its layout is a great advance on the first edition. The chapter on difficulties of existing nomenclature is better balanced and forms an admirable introduction. This is now followed by a chapter giving a clear and concise introduction to the procedures of the cipher, indicating how it may be applied to the majority of comparatively simple compounds. A full analytical discussion follows in the next four chapters, which deal successively with the basic carbon skeleton, the heterocyclic compounds, functional groups and with complex heterogeneous structures, polymers, carbohydrates and proteins. The concluding two chapters deal with the relation between cipher and spoken nomenclature and with computation and the mechanical use of the notation.

A very large amount of new work has gone to the preparation of this edition, and the clear presentation should facilitate its consideration by the general body of organic chemists. Whether or not the system is internationally adopted or widely used, Dr. G. M. Dyson has assuredly eamed the respect and gratitude of the organic chemist for a most pertinacious attack on a fomplex if not intractable problem. R. B.

\section{Between Pacific Tides}

An Account of the Habits and Habitats of some Five Hundred of the Common, Conspicuous Seashore Invertebrates of the Pacific Coast between Sitka, Alaska, and Northern Mexico. By Edward F. Ricketts and Jack Calvin. Revised edition. Pp. xxvii $+365+46$ plates. (Stanford, Calif. : Stanford University Press; London: Oxford University Press, 1948.) 32s. $6 d$. net.

ESSRS. E. F. RICKETTS and J. Calvin have 1 revised their well-known book on the littoral fauna of the west coast of America. Written by laymen collectors fot the layman, it stimulates his curiosity about the prolific life of the sea-shore and deals with the subject from the ecological rather than the tannomic point of view. Animal communities of He protected outer coast, open coast, bays and estuaries, and wharf piles are described, each area being again subdivided according to the substratum. These chapters are illustrated by photographs from living animals, making forty-six plates, and 129 linedrawings. A few of the plates (for example, 39, 43) have lost somewhat in brightness; but the magnificent colour-plate of Pacific chitons, on its green back- ground, which forms the frontispiece, is a most attractive and useful addition. The littoral section has cross-references from text to plate and vice versa. The original text remains unaltered, except for the correction of minor errors.

The addenda consist of a chapter on plankton and a complete revision of the extensive bibliography. The former is more advanced in style than the popular portion of the book and contains many graphs showing seasonal changes in the phytoplankton and zooplankton, but no sketches or photographs of the living organisms. Surely the amateur needs some pictorial help on this subject, if he is to be able to link it up with the earlier section of the book? The foreword is written by John Steinbeck.

The Antarctic Ocean

By Russell Owen. Pp. 22, 14 plates. Museum Press, Ltd., 19 18 . net.

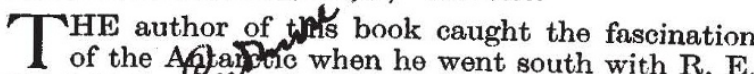
Byrd in the Artle America expedition of 1928-30 as special cqumespondent of 7 he New York 7 imes. He be pelld the stories of some of the best-known e Mfitions of all times with an eye to journalistic interbst rather than historical value. There is little new and practically nothing about the Antarctic Ocean, and very little about the Antarctic Continent, its glaciers and animal Iife. Mr. R. Owen is eautious about the Bransfield Palmer controversy over the discovery of what is now known as Graham Land, but he goes too far in asserting that C. Wilkes furnished proof of the continental character of Antarctic lands. There is very little in his pages about recent British and Norwegian work. Two dozen sketch-maps are a useful feature of the book.

R. N. R. B.

Subject Index to Periodicals, 1947

(Issued by the Library Association.) Pp. xi 311. (London: Library Association, 1949.) £5 5s. $0 d$.

7 HE princing singe in this valuable work for the generf reader is the change in size from quarto rymat which allows it to be shelved with the mais ity of other reference books. It is compiled on the plan of the 'dictionary catalogue', and the crdss-references increase its value in tracing references to unusual and out-of-the-way topics which might otherwise be overlooked. While it does not cover the highly specialized periodicals of which the contents are covered by sectional indexes or abstracts, the scientific worker will sometimes find it a useful supplement to such sources in completing a search, particularly on more general topics.

A New Dictionary of Chemistry<smiles>[C]#C</smiles>

Edited by Dr. Stephen Miall and L. Mackenzie Miall Second edition. Pp. ix +589 . (London, New York and Toronto: Longmanes, Green and Co., Ltd., 1949.) 60s. net.

T $N$ this segend edfion of a well-known work, an 1 opporfyur whis been taken to make many cor. rections the original text, and to add much new

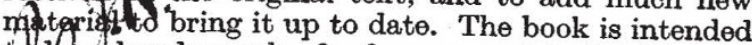
tif 2 e handy work of reference, and it should serve this burpose excellently. The reviewer notices that the sections include atomic energy, penicillin, strepto. mycin and pterins, but not lithium aluminium hydride, promethium and osmium carbonyl, to take a few examples at random. This dictionary should be in all school and college libraries. 